Zeszyty Naukowe Szkoły Głównej Gospodarstwa Wiejskiego

Ekonomika i Organizacja Gospodarki Żywnościowej nr 120, 2017: 175-187

DOI 10.22630/EIOGZ.2017.120.47

\author{
Anna Dąbrowska, Mirosława Janoś-Kresło \\ Instytut Zarządzania \\ Szkoła Główna Handlowa w Warszawie
}

\title{
Zachowania młodych konsumentów na rynku m-zakupów
}

\section{Wstęp}

Postęp technologiczny sprawił, że coraz częściej konsumenci łączą się z Internetem, wykorzystując w tym celu urządzenia mobilne, a zwłaszcza smartfon i tablet. Technologie mobilne mają coraz większy wpływ na sposób naszego funkcjonowania w różnych dziedzinach życia, w tym także na zachowania nabywcze. Powoduje to dynamiczny rozwój rynku m-commerce i wzrost jego znaczenia, także w Polsce.

Globalna sprzedaż mobilna w 2018 roku osiągnie 626 mld USD, zrównując się z wynikami całego e-commerce z 2013 roku, a liczba aktywnych urządzeń mobilnych w 2018 roku ma wynieść 8,2 mld. Rozwój m-commerce będzie miał znaczący wpływ na sposób robienia zakupów. Już obecnie 90\% konsumentów korzysta ze smartfonów w celu sprawdzenia lokalizacji czy godzin otwarcia sklepu [Wojciechowski 2015]. Według firmy Zanox ${ }^{1}$ badającej zachowania konsumentów na międzynarodowych rynkach (wśród których były kraje Beneluksu, Europy Wschodniej, Austria, Włochy, kraje nordyckie, Hiszpania, Szwajcaria i Wielka Brytania) wynika, że konsumenci z Wielkiej Brytanii i krajów nordyckich dokonali najwięcej transakcji mobilnych, najmniej Szwajcarzy, ale to oni generują największe średnie wartości zamówień w branży turystyki online [Ecommerce News 2016].

Polski rynek m-commerce należy do najszybciej rozwijających się w Europie. W 2015 roku wartość rynku m-commerce w Polsce szacowna była na

\footnotetext{
${ }^{1}$ Zanox to sieć afiliacyjna w sektorze handlu elektronicznego i programów partnerskich wchodząca w skład grupy Zanox. W 2016 roku podjęto decyzję o połączeniu Zanox i Affiliate Window pod ujednoliconą marka Awin.
} 
około 2,5 mld zł. Jeśli trend utrzyma się, krajowy rynek może wyprzedzić rynki m-commerce takich krajów, jak: Dania, Norwegia, Austria czy Wielka Brytania. W 2015 roku udział kupujących online przez urządzenia mobilne w Polsce wyniósł 8,3\%, w Wielkiej Brytanii było to 31,1\%, w Niemczech 29,7\%, w Hiszpanii 29,1\%, a we Francji 22,1\% [Ecommerce News 2016]. Według Polskiej Izby Handlu do 2018 roku Polska będzie liderem m-commerce w Europie pod względem wartości per capita [Anonim 2016].

Badanie PayPal w 2015 roku pokazało, że w Polsce było 26\% kupujących online $\mathrm{z}$ użyciem smartfona w ostatnich 12 miesiącach przed badaniem. Był to większy odsetek niż w krajach nordyckich (Szwecja - 21\%, Norwegia - 24\%, Dania $-20 \%$, Holandia - 17\%) czy Austrii - 23\%, ale mniejszy niż we Włoszech $-36 \%$, w Hiszpanii i Rumunii - po 34\%, Wielkiej Brytanii-33\%. W tym samym badaniu szacuje się, że najwyższe roczne wskaźniki wzrostu w latach 2013-2016 w handlu mobilnym będą w Europie na poziomie 42\%, a w handlu online $13 \%$. W Polsce będzie to $33 \%$, co oznacza trzykrotnie większy wzrost niż całego handlu online (10\%) [Ecommerce News 2017].

\section{Młodzi konsumenci jako segment rynku m-commerce}

Najbardziej aktywnymi konsumentami na rynku m-zakupów, jak pokazują wyniki rożnych badań, są osoby młode, w wieku do 35 lat. Gracz i Ostrowska [2014] zwracają uwagę, że jest to bardzo atrakcyjny i rozwojowy segment rynku dóbr konsumpcyjnych, posiadający stosunkowo duży, a przede wszystkim perspektywiczny, potencjał ekonomiczny. Jak słusznie zauważa Adamczyk [2014], młodzi konsumenci reprezentują istotną siłę nabywczą i decyzyjną, gdyż dysponują coraz większymi środkami finansowymi, które zagospodarowują według własnych potrzeb oraz wywierają znaczący wpływ na decyzje zakupowe podejmowane $\mathrm{w}$ rodzinie.

Analizując homo consumens w kontekście młodych konsumentów, wyróżniającą ich cechą jest wygoda, której oczekują od życia. Mając szeroki wybór dóbr i usług, współczesny konsument jest jednostką poszukującą nowych produktów oraz substytutów. Ważnym elementem podejmowania decyzji jest informacja, której wyselekcjonowanie w natłoku wiadomości wymaga umiejętności jej filtrowania. To sprawia, że młodzi konsumenci stają się bardziej odporni na działania marketingowe. Skuteczniejszym narzędziem poszukiwań dóbr i usług stał się Internet, który poprzez dostarczanie szybkiej informacji przy wykorzystaniu urządzeń mobilnych (smartfona, tabletu) pomaga ludziom młodym lepiej wyrazić siebie, znaleźć spersonalizowane produkty skrojone na miarę. 
Naturalnie podejmowanym decyzjom nabywczym towarzyszy ryzyko [Garbarski 1998, Maciejewski 2010]:

- funkcjonalne - obawa o spełnienie zarówno podstawowych funkcji produktu, jak i dodatkowych,

- fizyczne - lęk o bezpieczeństwo produktów w procesie użytkowania; im większe utechnicznienie produktu, tym większe zagrożenie dla konsumenta,

- finansowe - możliwość wystapienia straty pieniężnej w sytuacji, gdyby zakup okazał się zakupem nietrafionym,

- $\quad$ społeczne - akceptacja wyboru przez grupy społeczne, w której konsument przebywa, lub do uczestnictwa w której aspiruje, rodziny oraz znajomych; ważne są opinie kształtowane przez środowisko,

- psychologiczne - wpływ zakupu na indywidualne poczucie własnej wartości, godności czy na sposób myślenia konsumenta o sobie samym (postrzeganie własnego wizerunku).

Zmniejszenie ryzyka wymaga przemyślanych zakupów, tymczasem jak wynika z raportu mShopper 2.0. Polacy na zakupach mobilnych [Mobile Institute 2016] konsumenci kupujący mobilnie chcą mieć produkt od razu, lubią kupować spontanicznie i nie boją się takich zakupów. W ich przekonaniu zbyt długie podejmowanie decyzji odbiera przyjemność z zakupu. Lubią jednak konsultować zakup z bliskimi, prawdopodobnie, aby ograniczyć „ryzyko społeczne”.

Budowanie swojego wizerunku poprzez posiadanie dóbr i korzystanie z usług stało się nieodłącznym elementem życia szczególnie młodych konsumentów. Współczesny młody konsument coraz częściej jest świadomy swoich motywów i potrzeb, co oznacza, że poszukuje takich produktów, które dostarczają mu najwięcej satysfakcji przy jak najmniejszym obciążaniu budżetu, czyli następuje maksymalizacja funkcji użyteczności konsumenckiej. Niewątpliwie realizacji takiego podejścia sprzyjają e-zakupy, ale także coraz bardziej powszechne wśród osób młodych m-zakupy. Jak twierdzi Andrzej Garpich z CEO Polskie Badania Internetu (PBI), zakupy mobilne wyszły z niszy przeznaczonej dla trendsetterów (osób przekazujących opinię ,jaki produkt jest w rzeczywistości”, a nie jak marka/firma chce go przedstawić) i cyfrowych geeków (ludzie-pasjonaci, którzy dążą do pogłębienia swojej wiedzy i umiejętności w danej dziedzinie, w tym przypadku w dziedzinie usług cyfrowych) [Mobile Institute 2016].

Jak wynika z przywołanego już raportu mShopper 2.0. Polacy na zakupach mobilnych ${ }^{2}$, wśród ludzi młodych (w wieku 15-34 lat) postępuje proces zastępowania laptopa i PC smartfonem i tabletem. W 2016 roku w porównaniu

\footnotetext{
${ }^{2} \mathrm{~W}$ ramach badania ilościowego zebrano opinie 3174 Polaków, w tym 1185 kupujących z wykorzystaniem urządzeń mobilnych (smartfona bądź tabletu). Wykorzystano responsywne ankiety CAWI (ang. computer-assisted web interview) emitowane na stronach WWW oraz w wysyłce mailowej. Badanie przeprowadzono w terminie 6-16 luty 2016 roku.
} 
do roku poprzedniego osoby w wieku 15-18 lat i 19-24 lata nabyły o 6 p.p. więcej urządzeń mobilnych (analogicznie: z 39 do $45 \%$ i z 55 do $61 \%$ ), a w grupie wiekowej 25-34 lata poziom nie zmienił się (po 62\%). W przypadku tabletów w 2016 roku w stosunku do 2015 roku nastapił wzrost penetracji w grupie 19-24 lata o 10 p.p. (z 33 do 43\%), a w grupie 25-34 lata o 13 p.p. (z 31 do 44\%). W grupie osób najmłodszych sytuacja nie uległa zmianie (po 30\%).

Osoby młode wykorzystują urządzenia mobilne do różnych czynności, między innymi przeglądają Internet, wysyłają SMS-y i MMS-y, robią zdjęcia/nagrywają wideo, słuchają muzyki, korzystają z mediów społecznościowych.

Zmiany zachodzące w latach 2015-2016 w przypadku wykorzystania urządzeń, w tym mobilnych, do zakupów są niejednorodne w poszczególnych grupach wiekowych. W grupie wiekowej 15-18 lat odnotowano wzrost wykorzystania zarówno laptopów/PC (o 15 p.p.), jak i urządzeń mobilnych - smartfonu (o 9 p.p.), a spadek o 8 p.p. korzystania $z$ innego urządzenia mobilnego - tabletu. W grupie wiekowej 19-24 lata zwiększyło się wykorzystanie wszystkich urządzeń, przy czym w przypadku laptopa/PC jest to wzrost o 3 p.p., a jeżeli chodzi o urządzenia mobilne: aż 24 p.p. w przypadku smartfona i 20 p.p. tabletu. W trzeciej grupie wiekowej 25-34 lata zmalało wykorzystanie laptopa/PC o 11 p.p., a wzrosło smartfona o 17 p.p. i tabletu o 5 p.p. (rys. 1).

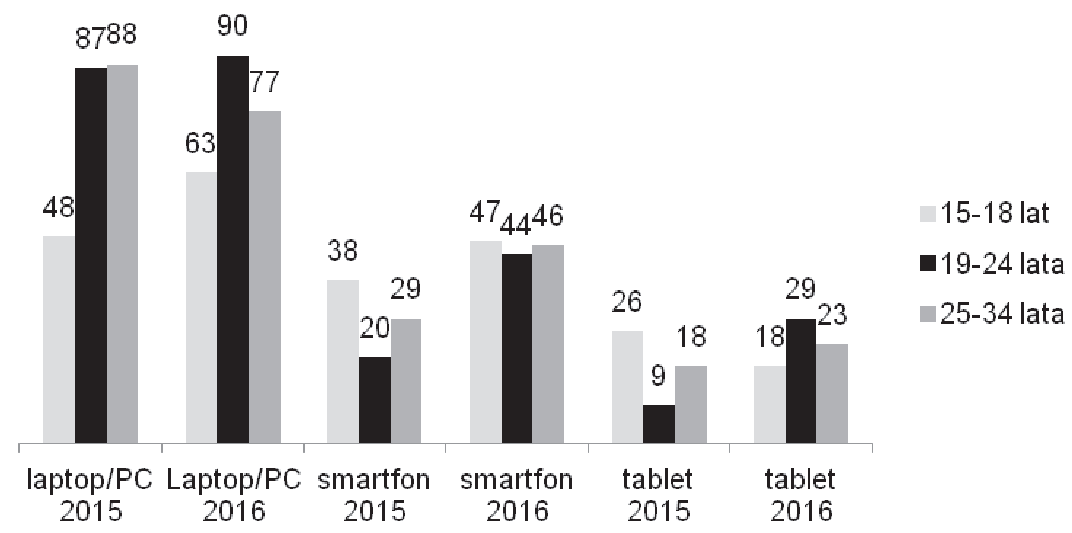

\section{Rysunek 1}

Wykorzystanie urządzeń, w tym mobilnych do zakupów w latach 2015-2016 [\%] Źródło: Opracowanie na podstawie Mobile Institute [2016].

Zmiany zachodzace $\mathrm{w}$ latach 2015-2016 w przypadku wykorzystania urządzeń, w tym mobilnych, do zakupów są niejednorodne w poszczególnych grupach wiekowych. W grupie wiekowej 15-18 lat odnotowano wzrost zarówno wykorzystania laptopów/PC (o 15 p.p.), jak i urządzenia mobilnego, jakim jest smartfon (o 9 p.p.), a spadek w przypadku korzystania z innego urządzenia mobilnego, jakim jest tablet (o 8 p.p.). W grupie wiekowej 19-24 lata wzrost wyko- 
rzystania dotyczył wszystkich urządzeń, przy czym w przypadku laptopa/PC był o 3 p.p., w przypadku urządzeń mobilnych: aż o 24 p.p. w przypadku smartfona i o 20 p.p. tabletu. W trzeciej grupie wiekowej 25-34 lata zmalało wykorzystanie laptopa/PC o 11 p.p., a wzrosło smartfona o 17 p.p. i tabletu o 5 p.p.

Można zatem powiedzieć, że popularność urządzeń mobilnych typu smartfon jako urządzenia zakupowego wzrosła w każdej grupie demograficznej. Smartfon staje się nieodzownym asystentem zakupowym młodych konsumentów. Zapewne jest to ważny sygnał dla marketerów, których rolą jest jak najskuteczniejsze dotarcie z oferta, informacją na przykład o promocjach do potencjalnego klienta. Wielokanałowość komunikacji jest niewątpliwie szansą na pozyskanie nowych klientów.

Wyniki badania M-commerce. Kupuję mobilnie 2016 pokazują, że grupy wiekowe 18-24 lata i 25-34 lata najintensywniej wykorzystują różne urządzenia mobilne. Największe zmiany zaobserwowano jednak w grupie najmłodszej (do 18 lat), która silniej w porównaniu z rokiem poprzednim zaczęła w celach zakupowych wykorzystywać urządzenia mobilne. Grupa ta jest też zainteresowana zakupowo innowacjami technologicznymi, takich jak smartwatch i smart TV. W każdej grupie wiekowej najbardziej na znaczeniu zyskał smartfon, ale najbardziej w grupie najmłodszych konsumentów [Mobile Institute 2016].

Warto przyjrzeć się, dlaczego młodzi konsumenci kupują mobilnie (rys. 2).

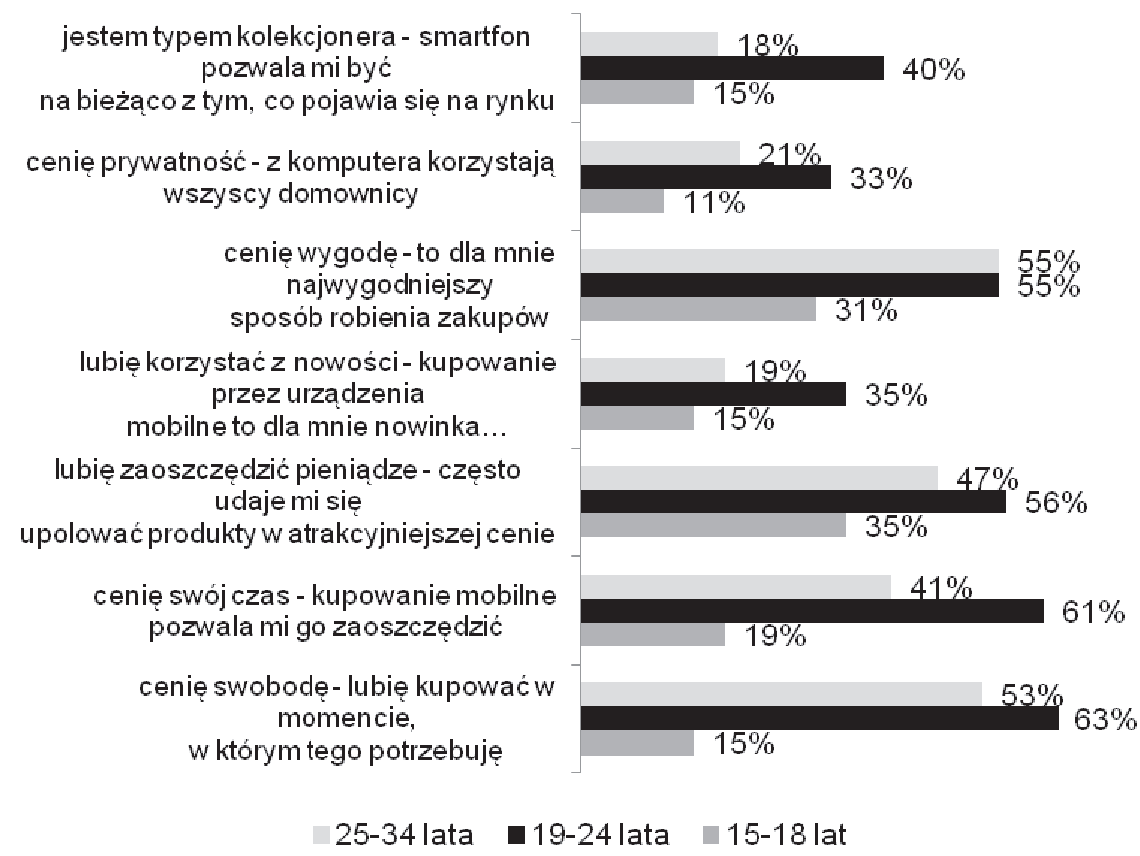

\section{Rysunek 2}

Powody kupowania mobilnie przez osoby w wieku 15-34 lata [\%]

Źródło: Opracowanie na podstawie Mobile Institute [2016]. 
Osoby w wieku 15-18 lat dokonują m-zakupów, ponieważ lubią oszczędzać pieniądze, często udaje im się upolować produkty $\mathrm{w}$ atrakcyjniejszej cenie oraz cenią wygodę i jest to dla nich najwygodniejszy sposób robienia zakupów. Z kolei osoby w wieku 19-24 lata są grupą która wskazała na wszystkie wyróżnione powody, przy czym najwięcej osób ceni swobodę, nieco mniej ceni swój czas, a co druga osoba lubi oszczędzać pieniądze, lub ceni wygodę. Największy odsetek wśród całej grupy młodych konsumentów uważa się za kolekcjonera, smartfon pozwala im być na bieżąco z tym, co pojawia się na rynku ( $40 \%$ wskazań). Osoby z najstarszej grupy wiekowej (25-34 lata) wskazały na trzy główne powody: cenią wygodę, cenią swobodę oraz lubią oszczędzać pieniądze. Warto w tym kontekście odwołać się do innych badań, które także wskazują na znaczenie czasu, a właściwie jego oszczędność jako jedną z najważniejszych zalet zakupów przez urządzenia mobilne. Zakupy mobilne pozwalają konsumentowi: oszczędzić czas - 73\%, znaleźć lepsze oferty - $69 \%$, zrobić ,zakupy po drodze” $-69 \%$, w trakcie wykonywania innych czynności - 63\%, bez czekania w kolejce - 55\% [Latitude Research 2012].

W badaniu mShopper 2.0 poproszono także osoby młode o ocenę m-zakupów. Najwyższe oceny m-zakupy uzyskały w grupie wiekowej 18-24 lata. Częściej niż co druga osoba $\mathrm{z}$ tej grupy wiekowej (55\%) uważa, że jest to bardzo łatwe, $36 \%$, że raczej łatwe. Nikt nie wskazał na opcję bardzo trudne. W grupie wiekowe 15-18 lat największy odsetek badanych wśród badanej populacji wskazał na odpowiedzi: bardzo trudne (15\%) i raczej trudne (26\%). Z kolei osoby w wieku 25-34 lata oceniały najczęściej, że m-zakupy są bardzo łatwe (49\%) lub raczej łatwe $(40 \%)$. W tej grupie niemal co dziesiąta osoba $(9 \%)$ nie potrafiła udzielić jednoznacznej odpowiedzi.

Pomimo dobrej oceny zakupów mobilnych kupujący w tym kanale konsumenci z jakiegoś powodu przerwali zakup. Niestety nie przedstawiono tego problemu w podziale na grupy wiekowe, ale warto przytoczyć powody. W sumie $65 \%$ wskazań dotyczyło uwarunkowań zewnętrznych, tzn. niezależnych od samego kanału mobilnego. Obiektywne trudności to: przerwane połączenie internetowe (28\%), niewygodne aplikacje i strony sklepów (14\%), długi proces zakupowy (12\%), niedostosowanie stron do zakupów mobilnych (10\%) i konieczność podawania swoich danych (8\%). Warto podkreślić, że od sprzedawców zależy bezpośrednio $41 \%$ napotykanych przez konsumentów trudności i na to powinni zwracać uwagę handlowcy. Na pewno warto przeprowadzić szkolenia personelu zwiększające ich kompetencje. Jest to ważne wobec reakcji na trudności zakupowe. Dane dotyczą lat 2015 i 2016, co pozwala wnioskować o zmianie w świadomości m-zakupowiczów. Podejmowano następujące reakcje:

- ograniczam korzystanie z serwisów sprawiających trudność (27\%; w 2015 r. $28 \%$ );

- $\quad$ sprawdzam konkurencyjne serwisy (27\%; w 2015 r. 28\%); 
- ostrzegam innych przed trudnościami w danym serwisie (25\%; w 2015 r. $12 \%)$;

- zniechęcam się do serwisów, które sprawiają trudność (16\%; w 2015 r. $30 \%$;

- staram się robić jednak zakupy w bardziej klasyczny sposób (11\%; w 2015 r. $38 \%)$.

Z powyższych danych wyłania się dość ciekawy obraz konsumentów kupujących przy wykorzystaniu urządzeń mobilnych. Mimo trudności znacznie mniej osób niż w 2015 roku chce zrezygnować z tego kanału zakupowego, nie tak łatwo zniechęca się też do serwisów, które sprawiają trudności, ale zdecydowanie więcej osób ostrzega innych przed trudnościami w danym serwisie. Można zatem powiedzieć, że wzrasta społeczna odpowiedzialność konsumentów i świadomość konsumencka [Dąbrowska i Janoś-Kresło 2012].

\section{Młodzi konsumenci na m-zakupach}

Młode osoby, bez względu na grupę wiekową, najchętniej robią m-zakupy w sklepach internetowych, platformach zakupowych/aukcjach. Największy odsetek przypada na grupe wiekową 19-24 lata (odpowiednio: 85 i 68\%). Osoby najmłodsze niemal w ogóle nie korzystają z zakupów grupowych, ale na równi z osobami ze starszych grup wiekowych robią zakupy za pośrednictwem klubów zakupowych. Serwisy ogłoszeniowe są popularne na równi w grupie osób w wieku 19-24 lata i 25-34 lata (odpowiednio 51 i 53\%). Porównywarki cenowe preferują bardziej osoby w wieku 19-24 lata (43\%), podobna sytuacja dotyczy sklepów z aplikacjami mobilnymi (34\%) - rysunek 3.

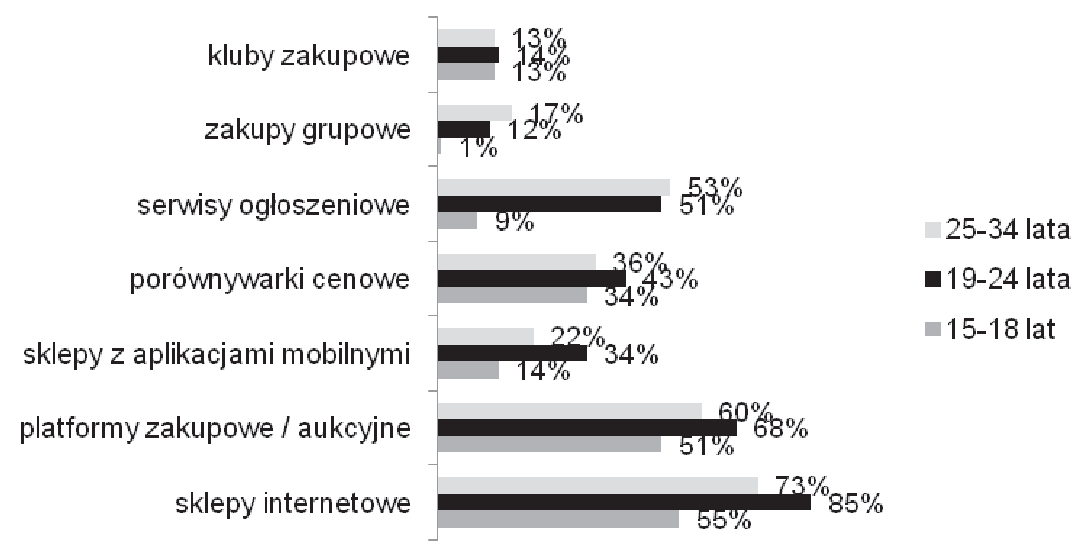

\section{Rysunek 3}

Miejsce robienia m-zakupów [\% wskazań]

Źródło: Opracowanie na podstawie Mobile Institute [2016]. 
Ludzie młodzi, podobnie jak osoby starsze, najczęściej sięgają po 5 najpopularniejszych, topowych kategorii zakupowych wielokanałowo. W analizowanych grupach wiekowych najpopularniejsza w zakupach jest elektronika, a następnie moda i uroda (rys. 4). Osoby najmłodsze najmniej są zainteresowane kulturą i rozrywką (7\%). Są to usługi relatywnie drogie, jak na kieszeń młodego człowieka. Zwraca uwagę kategoria sport i wypoczynek. Popyt na te usługi kupowane za pośrednictwem urządzeń mobilnych systematycznie rośnie.

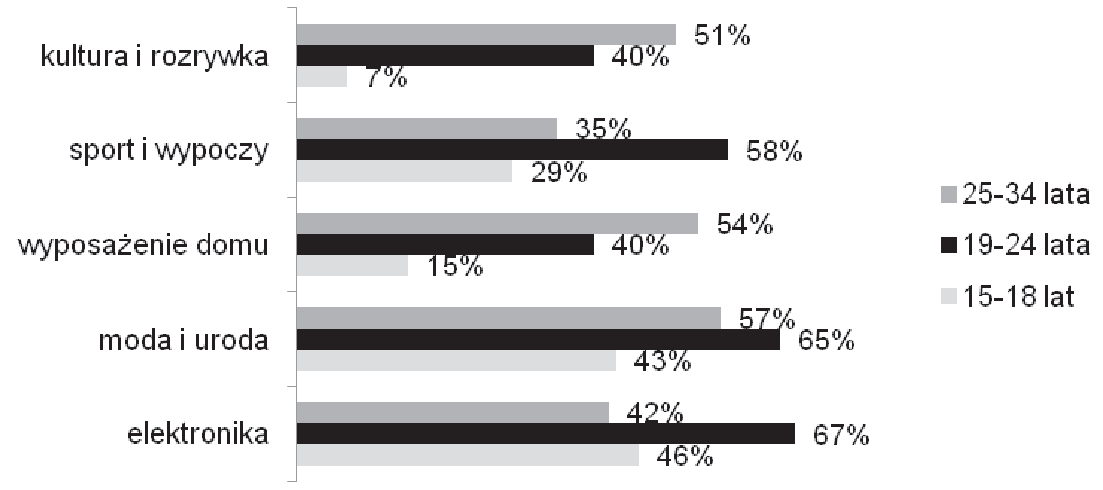

\section{Rysunek 4}

Najpopularniejsze kategorie zakupowe [\% wskazań]

Źródło: Opracowanie na podstawie Mobile Institute [2016].

Osoby w wieku 15-18 lat dokonują m-zakupów najczęściej więcej niż 5 razy (38\%) lub 2-5 razy (32\% wskazań) w skali ostatnich 12 miesięcy. Większość osób z tej grupy wiekowej (60\%) wydało podczas ostatniego zakupu 51-150 zł. Co druga osoba z grupy wiekowej 19-24 lata robiła zakupy więcej niż 5 razy w ciągu ostatnich 12 miesięcy, a co trzecia osoba 2-5 razy, co trzecia osoba wydała na zakupy 51-150 zł, a 39\% wydało więcej na m-zakupy, nawet powyżej 2000 zł. W grupie wiekowej 25-34 lata wskaźniki częstotliwości m-zakupów kształtowały się odpowiednio: 53 i 30\%, a 36\% wydało 51-150 zł, ale 39\% konsumentów z tej grupy wydało więcej niż 150 zł.

Współczesny konsument ma możliwość regulowania należności za dokonane zakupy przy wykorzystaniu różnych form płatności. Są to: płatność przelewem bankowym, szybkie przelewy, płatność za pobraniem, płatność kartą płatnicza, SMS/MMS, płatność smartfonem, płatność mobilna, płatność ratalna, płatność odroczona. Przeanalizowano kupujących wielokanałowo i kupujących mobilnie i wyniki kształtują się następująco:

- płatność przelewem bankowym: 56\% (wielokanałowo) i 35\% (mobilnie);

- $\quad$ szybkie przelewy: 56 i 35\%;

- płatność za pobraniem: 46 i 28\%; 
- płatność kartą płatniczą: 31 i 21\% (coraz mniejsza popularność tej formy);

- SMS/MMS: 20 i 17\%;

- płatność smartfonem: 30 i 22\%;

- płatność ratalna: 17 i $11 \%$.

Na rysunku 5 przedstawiono preferowane formy płatności wśród ludzi młodych.

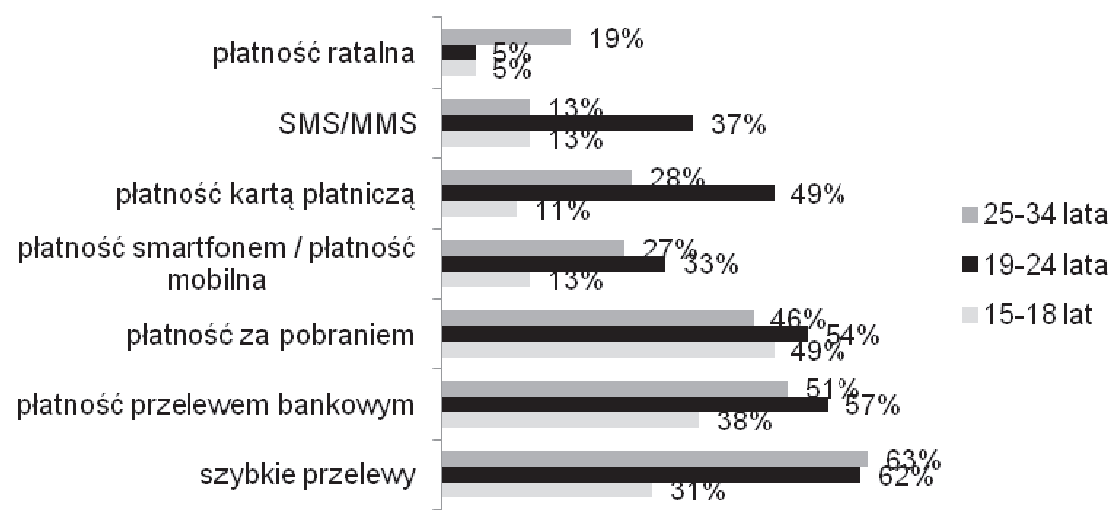

\section{Rysunek 5}

Formy płatności preferowane przez ludzi młodych [\%]

Źródło: Opracowanie na podstawie Mobile Institute [2016].

Osoby w wieku 15-18 lat preferują płatność za pobraniem (49\% wskazań), płatność przelewem bankowym (38\%) i szybkie przelewy (31\%). Osoby w wieku 19-34 lata zdecydowanie preferują szybkie przelewy (62\% wskazań w grupie 19-24 lata i 63\% wskazań w grupie 25-34 lata). Na drugim miejscu wskazano płatność przelewem bankowym (57 i 51\% wskazań), a na trzecim płatność za pobraniem (54 i 46\% wskazań).

Z badań autorek dotyczących kompetencji konsumentów wynika ${ }^{3}$, że z możliwości dokonywania płatności przez telefon komórkowy korzystał co dziewiąty respondent, a 3\% kompetentnych konsumentów robiło to regularnie. W grupie dokonujących płatności tym sposobem od czasu do czasu przeważającą grupa były osoby w wieku 30-39 lat. Usługa ta ze względu na powszechność posiadania i korzystania z telefonów komórkowych przez różne grupy wiekowe Polaków ma duży potencjał rozwoju. Z możliwości płacenia kartą płatniczą z funkcją

\footnotetext{
${ }^{3}$ Badanie przeprowadzono wśród 1000 respondentów w sierpniu 2013 roku. W badaniu głównym jako technikę badawczą wykorzystano wywiad telefoniczny CATI składający się z dwóch modułów. Pierwszy obejmował pytania o faktyczne zachowania konsumenckie i respondentów. Drugi zawierał niezbędny do segmentacji test stwierdzeń badający postawy konsumentów. Dwa moduły pozwoliły na konfrontację dwóch poziomów funkcjonowania konsumentów na rynku: behawioralnego oraz motywacyjnego. Respondentami byli dorośli Polacy w wieku 18-74 lata.
} 
zbliżeniową korzystały zazwyczaj osoby w wieku 18-29 lat [Dąbrowska i in. 2015].

Jakie są deklaracje zakupowe osób młodych? Ich postawy przedstawia rysunek 6 .

\section{Rysunek 6}

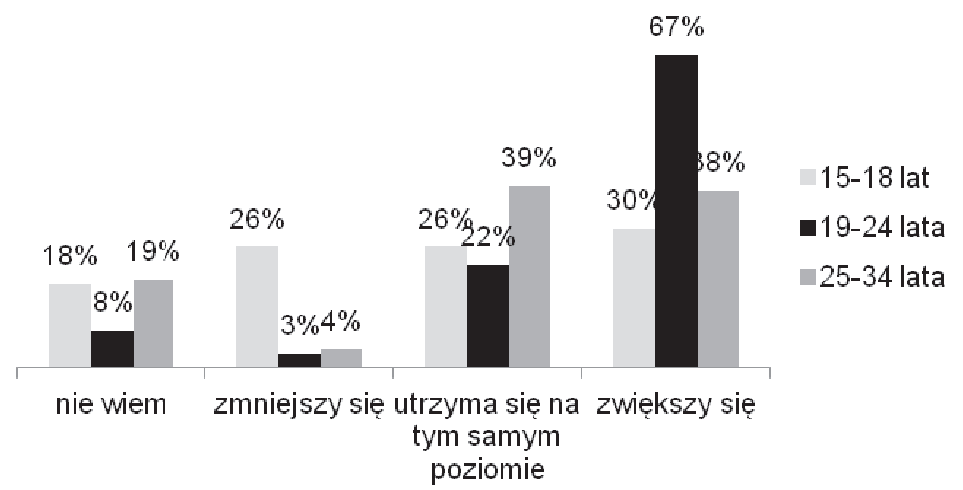

Deklaracje zakupowe osób w młodych [\%]

Źródło: Opracowanie na podstawie Mobile Institute [2016].

W grupie wiekowej 15-18 lat, ale także 25-34 lata co piąta osoba nie ma sprecyzowanych planów co do przyszłości m-zakupów. Co czwarta osoba w najmłodszej grupie wiekowej przewiduje zmniejszenie zakupów przy wykorzystaniu urządzeń mobilnych. W przypadku najmłodszych osób na odpowiedzi mogła wpływać niestabilność finansowa, często brak regularnego comiesięcznego dopływu środków finansowych. Osoby z najstarszej grupy wiekowej (najbardziej ustabilizowane finansowo) planują albo utrzymanie m-zakupów na tym samym poziomie bądź ich zwiększenie. Z punktu widzenia przedsiębiorstw jest to najatrakcyjniejszy segment konsumentów.

Czy ludzie młodzi dotychczas nie robiący m-zakupów podejmą takie działania w najbliższych miesiącach, czyli do końca 2016 roku? Takie deklaracje złożyły osoby w każdej z analizowanych grup wiekowych (rys. 7).

Zdecydowanie i raczej zrobi zakupy przy wykorzystaniu urządzeń mobilnych 56\% badanych osób w wieku 15-18 lat, 52\% osób w wieku 19-24 lata i 51\% osób w wieku 25-34 lata. Można zatem powiedzieć, że przedsiębiorstwa muszą podjać wysiłek i działania marketingowe, aby przekonać do m-zakupów tych, którzy odpowiedzieli raczej nie i zdecydowanie nie. Odpowiadających raczej nie było zdecydowanie więcej, co oznacza, że nie wykluczają oni definitywnie m-zakupów. Potrzebna jest tylko skuteczna strategia budowania relacji z nimi, ciekawej oferty i skutecznej komunikacji z tym segmentem rynku. 


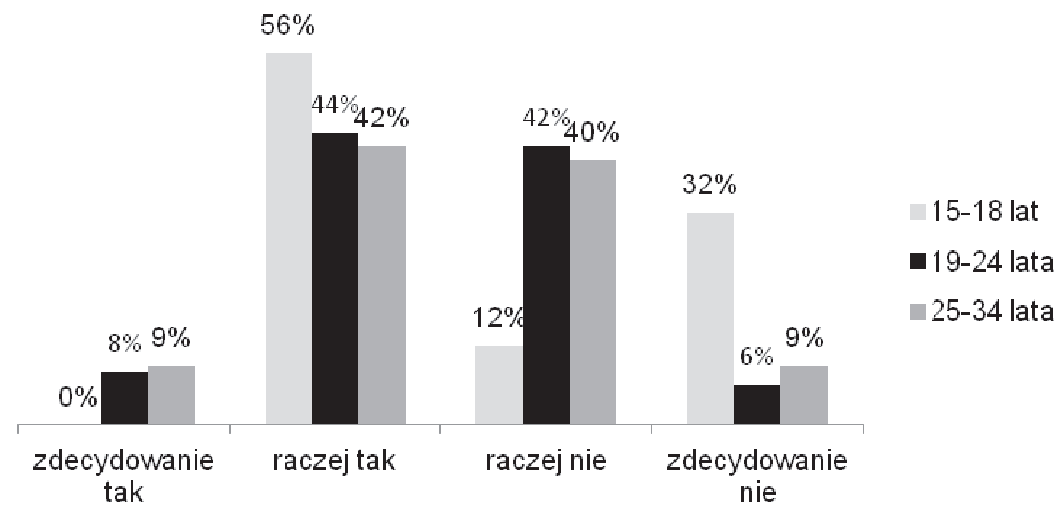

Rysunek 7

Deklaracja zakupów mobilnych przez internautów niekupujących przy wykorzystaniu urządzeń mobilnych [\%]

Źródło: Opracowanie na podstawie Mobile Institute [2016].

\section{Podsumowanie}

Rynek zakupów mobilnych to jeden z najszybciej rozwijających się obecnie rynków, także w Polsce. Rozwojowi tego rynku sprzyja wzrastająca liczba użytkowników smarfonów i tabletów, którzy obecnie stanowią większość w Internecie. Według badania Gemiusa/PBI w czerwcu 2017 roku (Wyniki..., 2017) było ich w Polsce 20,7 mln. Czynnikiem sprzyjającym są także zalety urządzeń mobilnych, które pozwalają na skrócenie czasu procesu zakupu od podjęcia decyzji o zakupie, poprzez porównanie ofert, aż do dokonania płatności.

Konsumentami szczególnie aktywnymi na rynku zakupów mobilnych są młodzi konsumenci, którzy są nie tylko lepiej wyposażeni w urządzenia mobilne, ale także korzystają oraz zamierzają z nich korzystać coraz częściej, robiąc zakupy. Współcześni konsumenci są konsumentami oczekującymi, że zakupy będą łatwe, wygodne i przyjemne. Jednocześnie są to konsumenci bardziej świadomi, otwarci na nowości, ale też niecierpliwi. Stanowi to zatem duże wyzwanie dla przedsiębiorstw prowadzących lub zamierzających prowadzić handel poprzez kanał mobilny.

\section{Literatura}

Anonim, 2016: Uwierz w potencjał zakupów mobilnych, Biuletyn Polskiej Organizacji Handlu $36(5), 7$.

ADAMCZYK G., 2014: Wybrane aspekty zachowań młodych konsumentów w nowych realiach rynkowych, Handel Wewnętrzny 1 (354), 5-16. 
DĄBROWSKA A., BYLOK F., JANOŚ-KRESŁO M., KIEŁCZEWSKI D., OZIMEK I., 2015: Kompetencje konsumentów. Zrównoważona konsumpcja. Innowacyjne zachowania, PWE, Warszawa.

DĄBROWSKA A., JANOŚ-KRESŁO M., 2012: Etyka działalności przedsiębiorstw a etyka postępowania konsumentów, Marketing i Rynek 1, 10-16.

Ecommerce News, 2016: Mobile Shopping Behaviors in Europe, https://ecommercenews. eu/mobile-shopping-behaviors-europe [dostęp: 10.07.2017].

Ecommerce News, 2017: Mobile Commerce in Europe, https://ecommercenews.eu/mobilecommerce-europe [dostęp: 10.07.2017].

GARBARSKI L., 1998: Zachowania nabywców, PWE, Warszawa.

GRACZ L., OSTROWSKA I., 2014: Młodzi nabywcy na e-zakupach, Placet, Warszawa.

Izba Gospodarki Elektronicznej, 2016: M-commerce. Kupuję mobilnie, http://ecommercepolska.pl/files/7514/8000/0754/M-commerce_Kupuje_mobilnie_2.0_listopad_2016_2.pdf [dostęp: 10.07.2017].

Latitude Research, 2012: Next-gen Retail: Mobile and Beyond ${ }^{\circ}$, http://files.latd.com/Latitude-Next-Gen-Retail-Study.pdf [dostęp: 10.07.2017].

MACIEJEWSKI G., 2010: Ryzyko w decyzjach nabywczych konsumentów, Wydawnictwo Uniwersytetu Ekonomicznego w Katowicach, Katowice.

Mobile Institute, 2016: mShopper 2.0. Polacy na zakupach mobilnych, http://www.ecommercepolska.pl/files/3714/5923/9618/mShopper2.0PolacyNaZakupachMobilnych_marzec2016.pdf [dostęp: 05.07.2017].

ShoppingShow.pl, 2014: ShoppingShow. Zwyczaje zakupowe konsumenta digitalnego. Badania jakościowe, http://rubikom.pl/fileadmin/do_pobrania/ShoppingShow_2014_RAPORT zwyczaje zakupowe konsumeta_digitalnego_q.pdf [dostęp: 05.07.2017].

Twenga Solutions, 2016: E-commerce in Europa2016: Facts \& Figures, https://www.twenga-solutions.com/it/insights/ecommerce-europa-2016 [dostęp: 09.07.2017].

WOJCIECHOWSKI M., 2015: M-commerce rośnie na świecie $i$ w Polsce, gomobi.pl/blogi/ m-commerce-rosnie-na-swiecie-i-w-polsce [dostęp: 05.07.2017].

\section{Abstrakt}

Niniejszy artykuł ma charakter empiryczny. Jego celem jest identyfikacja zachowań młodych konsumentów (w wieku 15-34 lata) na rynku m-zakupów, przy uwzględnieniu trzech grup: 15-18 lat, 19-24 lata i 25-34 lata. Jest to segment konsumentów bardzo wrażliwy na nowoczesne rozwiązania technologiczne i poszukujący nowości, co często jest wyrazem ich osobowości, wpisywania się w nowe trendy konsumenckie. W artykule wykorzystano głównie wyniki raportu mShopper 2.0. Polacy na zakupach mobilnych z 2016 roku oraz wyniki badania własnego wykonanego w 2013 roku na potrzeby projektu badawczego Kompetencje konsumentów jako stymulanta innowacyjnych zachowań i zrównoważonej konsumpcji (2011/03/B/HS4/04417).

Słowa kluczowe: zachowania konsumentów, m-zakupy 


\section{The behaviour of young consumers on the m-shopping market}

\section{Abstract}

This article is of an empirical nature. Its main objective is to identify the behaviour of young consumers (aged 15-34) on the m-shopping market, taking into consideration three age groups: $15-18,19-24$ and $25-34$. This segment is very sensitive to modern technological solutions and interested in novelties, which is often an expression of their personality and being in line with new consumer trends. The article is based mainly on the results of the report mShopper 2.0. Polacy na zakupach mobilnych from 2016 and the results of own research conducted in 2013 as a part of the research project Consumer Competence as a Stimulator of Innovative Behavior and Sustainable Consumption (2011/03/B/HS4/04417).

Key words: consumer behaviour, m-shopping 